\title{
Alpha 1-Antitrypsin Scarcity linked with Hepatic Disease
}

\author{
Mihir Y Parmar* and Sachin Kumar Sharma \\ Parul Institute of Pharmacy and Research, Parul University, India
}

Submission: July 01, 218; Published: September 20, 2018

*Corresponding author: Mihir Y Parmar, Parul Institute of Pharmacy and Research, Parul University, Vadodara, Gujarat, India, Tel: +91-9638330050; Email: mihir.parmar19105@paruluniversity.ac.in, mihirparmar4uonly@yahoo.com

\section{Abstract}

Alpha 1-Antitrypsin (AAT) insufficiency is the most common genetic cause of hepatic disease in children and genetic disease for which children undergo hepatic transplantation. It also causes cirrhosis and hepatocellular carcinoma in adults. Mutant Alpha 1 Antitrypsin $\mathrm{Z}$ molecule undergoes polymerization in the endoplasmic reticulum and that a subpopulation of Alpha Antitrypsin deficient individuals may be susceptible to hepatic injury because they also have a trait that reduces the efficiency by which the mutant Alpha Antitrypsin $\mathrm{Z}$ molecule is degraded in the endoplasmic reticulum.

Keywords: Alpha 1-antitrypsin; Hepatic disease

\section{Introduction}

Alpha-antitrypsin (AAT) also referred to as $\alpha 1$-proteinase (or protease) inhibitor ( $\alpha 1-\mathrm{PI})$ ) is a $52 \mathrm{kD}$ glycoprotein mostly secreted by hepatocytes and, to a lesser extent, by lung epithelial cells and phagocytes [1]. Alpha-1-antitrypsin (AAT) deficiency is estimated to affect three million people worldwide, [2] with patients typically developing lower zone emphysema at a relatively young age. People of Northern European and Iberian ancestry are at the highest risk for AAT alteration. Alpha-1 antitrypsin (AAT) deficiency is a common inherited cause of hepatic disease, with the most severe mutation found in 1:3500 live births and currently 180,000 individuals worldwide [2]. In children, $\mathrm{A} 1 \mathrm{AD}$ is the most frequent genetic etiology for pediatric hepatic disease and transplantation [3]. AAT deficiency (A1AD) was discovered in 1963 by Carl-Bertil Laurell (1919-2001), at the University of Lund in Sweden [4] Laurell, along with a medical resident, Sten Eriksson, made the discovery after noting the absence of the $\alpha 1$ band on protein electrophoresis in five of 1500 samples; three of the five patient samples were found to have developed emphysema at a young age. The link with hepatic disease was made six years later, when Harvey Sharp et al. described A1AD in the context of hepatic disease [5].

Point mutations lead to altered folding during alpha-1 antitrypsin biogenesis, and misfolded proteins form polymers that are retained within the endoplasmic reticulum of hepatocytes, rather than being systemically secreted [6]. Lack of AAT in lung permits uninhibited proteolytic damage to the connective tissue matrix, leading to emphysema in approximately $75 \%$ of patients [7]. Hepatic disease occurs due to aggregation of AAT polymers within the endoplasmic reticulum (ER) of hepatic cells, which form periodic acid-Schiff positive inclusions; a hallmark biopsy feature in A1AD related hepatic disease [8]. Hepatocyte injury is believed to be related to ER stress, mitochondrial dysfunction, and triggering of autophagy [9]. Variability in phenotypic expression in hepatic and lung disease, [10] is believed to reflect genetic [7] and environmental modifiers [11]. Cigarette smoking has been explained to be the greatest conjecturer of lung function impairment in A1AD buddies [12] and smoking cessation is the most effective treatment strategy [8].

Alpha-1 antitrypsin (AAT) deficiency is a common inherited cause of hepatic disease [3]. Clinical course of hepatic disease in particulars with $\mathrm{A} 1 \mathrm{AD}$ remains indisposed understood, but around $10 \%$ of those with undersupplied phenotypes are likely to experience significant morbidity secondary to hepatic disease at some point during their lifetime. Further future studies are required to better understand which individuals are prone to develop hepatic disease and the mechanism behind hepatic injury in these individuals. Detecting early fibrosis in individuals with A1AD is currently the best method of identifying those at risk of significant hepatic disease, and non-invasive procedure as an option to hepatic biopsy may soon be validated in this population. At this time, curative therapies available are limited to transplantation, but research in this field has been very promising, revealing novel mechanisms of action. Several innovative small molecule and gene-based strategies are now in clinical trials, with an overall approach of reducing proteotoxicity and maintaining protein homeostasis in the liver.

Deficient genotypes lead to production of an AAT protein that has legitimately potent antineutrophil elastase capacity, one therapeutic impression has been directed at trying to cause the liver to release its trapped AAT, thus relieving the congestion 
of the hepatocyte and reconstituting the circulating antielastase screen. The most promising candidates for this tactic are the synthetic chaperones and molecular interventions that try to avoid intracellular polymerization of the abnormal AAT.

\section{References}

1. M Luisetti, N Seersholm (2004) $\alpha_{1}$-Antitrypsin deficiency? 1 Epidemiology of $\alpha_{1}$-antitrypsin deficiency. Thorax 59 (2):164-169.

2. De Serres FJ (2003) Alpha-1 antitrypsin deficiency is not a rare disease but a disease that is rarely diagnosed. Environ Health Perspect 111(16):1851-1854.

3. Khan Z (2016) Pathogenesis of alpha-1 antitrypsin deficiency in the hepatic: new approaches to old questions. J Hepatic Res Disord Ther 2:00023.

4. Laurell CB, Eriksson S (1963) The electrophoretic alpha 1-globulin pattern of serum in alpha 1-antitrypsin deficiency. Scand J Clin Lab Invest. 15 (2): 132-140.

5. Sharp H, Bridges R, Krivit W, Freier E (1969) Cirrhosis associated with alpha-1-antitrypsin deficiency: a previously unrecognized inherited disorder. J Lab Clin Med. 73 (6): 934-939.

6. Perlmutter DH, Silverman GA (2011) Hepatic fibrosis and carcinogenesis in alpha1-antitrypsin deficiency: a prototype for chronic tissue damage in gain-of-function disorders. Cold Spring Harb Perspect Biol 3:123-145.

7. Kim WJ, Wood AM, Barker AF (2012) Association of IREB2 and CHRNA3 polymorphisms with airflow obstruction in severe alpha-1 antitrypsin deficiency. Respir Res 13:16.

8. Edgar RGPM, Bayliss S, Crossley D, Sapey E, Turner AM (2017) Treatment of lung disease in A1AD: a systematic review. Int J Chron Obstruct Pulmon Dis. 12:1295-1308.

9. Perlmutter DH, Silverman GA (2011) Hepatic fibrosis and carcinogenesis in A1AD a prototype for chronic tissue damage in gainof-function disorders. Cold Spring Harb Perspect Biol 3(3):123-145.

10. Stockley RA, Turner AM (2014) Alpha-1-Antitrypsin deficiency: clinical variability, assessment, and treatment. Trends Mol Med 20(2):105115.

11. Wood AM, Harrison RM, Semple S, Ayres JG, Stockley RA (2009) Outdoor air pollution is associated with disease severity in A1AD. Eur Respir J 34(2): 346-353.

12. O'Brien ME, Pennycooke K, Carroll TP (2015) The impact of smoke exposure on the clinical phenotype of A1AD in Ireland: exploiting a national registry to understand a rare disease. COPD 12(suppl 1): 2-9.

Your next submission with Juniper Publishers
will reach you the below assets
- Quality Editorial service
- Swift Peer Review
- Reprints availability
- E-prints Service
- Manuscript Podcast for convenient understanding
- Global attainment for your research
- Manuscript accessibility in different formats
( Pdf, E-pub, Full Text, Audio)
- Unceasing customer service
Track the below URL for one-step submission
https://juniperpublishers.com/online-submission.php

